\title{
Moche: Archaeology, Ethnicity, Identity
}

Moche: Arqueología, etnicidad, identidad

Moche: Archéologie, ethnicité, identité

Jeffrey Quilter

\section{CpenEdition}

\section{Journals}

Electronic version

URL: http://journals.openedition.org/bifea/1885

DOI: $10.4000 /$ bifea. 1885

ISSN: 2076-5827

\section{Publisher}

Institut Français d'Études Andines

\section{Printed version}

Date of publication: 1 August 2010

Number of pages: $225-241$

ISSN: 0303-7495

\section{Electronic reference}

Jeffrey Quilter, « Moche: Archaeology, Ethnicity, Identity », Bulletin de l'Institut français d'études andines [Online], 39 (2) | 2010, Online since 01 February 2011, connection on 07 November 2020. URL : http:// journals.openedition.org/bifea/1885; DOI : https://doi.org/10.4000/bifea.1885

Les contenus du Bulletin de l'Institut français d'études andines sont mis à disposition selon les termes de la licence Creative Commons Attribution - Pas d'Utilisation Commerciale - Pas de Modification 4.0 International. 


\title{
Moche: Archaeology, Ethnicity, Identity
}

\author{
Jeffrey Quilter*
}

\begin{abstract}
The two different modes of investigation in Art History and Anthropological Archaeology are discussed. This is followed by a consideration of these issues in relation to the Mochica archaeological culture. The "Mochica" have come to be considered a political or ethnic group and, in particular, considered as a prehistoric state. This essay questions these ideas and suggests that Moche is best considered as primarily a religious system. The ceremonial centers were likely places of pilgrimage with more complicated roles in politics than previous models have considered although changing roles through time must be considered.
\end{abstract}

Key words: Mochica, political organization, pilgrimage centers

\section{Moche: Arqueología, etnicidad, identidad}

\section{Resumen}

En este artículo se discuten dos métodos diferentes de investigación relativos a las disciplinas de la Historia del Arte y la Arqueología. Resulta una reflexión sobre estas aproximaciones metodologícas en cuanto a la cultura arqueológica Mochica. Gracias a los numerosos trabajos realizados sobre esta cultura, los «Mochica»son, hoy día, reconocidos como un grupo político o étnico, y aun más, se consideran como un estado prehistórico. Este ensayo cuestiona estos postulados, sugiriendo que la cultura Mochica hubiera sido más bien un sistema principalmente religioso. Así que los centros ceremoniales han sido probablemente lugares de peregrinación importantes con funciones políticas más complejas que lo sugerido por los modelos anteriormente propuestos. De igual manera debemos considerar la variación de sus funciones en el tiempo.

Palabras clave: Mochica, organización política, centros de peregrinación

* Deputy Director for Curatorial Affairs. Peabody Museum of Archaeology and Ethnology. Harvard University, Cambridge, Massachusetts, U.S.A. E-mail: quilter@fas.harvard.edu 


\section{Moche: Archéologie, ethnicité, identité}

\section{Résumé}

Dans cet article deux méthodes différentes de recherche propres à l'Histoire de l'art et àl'Archéologie sont remises en cause. II s'en suit une analyse de ces approches méthodologiques quant à la culture archéologique Mochica. À la suite des nombreux travaux qu'ils ont suscités, les «Mochica » sont aujourd'hui perçus comme un groupe politique ou ethnique, et même comme un état préhistorique. Cet essai remet en question ces postulats et suggère que la culture Mochica a plutôt consisté en un système religieux. Ainsi, les centres cérémoniaux ont probablement été des lieux de pèlerinage importants avec des fonctions politiques plus complexes que ceux que suggèrent les modèles précédents. De même, il faudra considérer la variation de leurs fonctions au fil du temps.

Mots clés : Mochica, organisation politique, centres de pèlerinage

\section{INTRODUCTION}

What was Moche? This is what I want to discuss here. Studies of this archaeological culture have been among the most dynamic in the prehistory of the Americas in the last two decades with an exponential growth in data that includes portable artifacts, murals, architecture, and elaborate burials. This increase in data has been met with various reactions in terms of how models of Moche politics and society have been modified. I wish to suggest, here, however, the preponderance of the evidence is such that it may be worthwhile to reconsider on a fundamental level what "Moche" was.

In reconsidering Moche, I will quickly review the history of studies, current theories of Moche, an alternate model for it, and some cautionary issues relating to that model and in general that may be useful in future studies.

\section{A SHORT HISTORY OF MOCHE STUDIES}

Although Max Uhle is credited as the first archaeologist to seriously engage with the Moche, through his excavations at the Huaca del Sol in the Moche Valley, it is Rafael Larco Hoyle who generally is considered to be the founder of contemporary Moche Studies. Larco not only collected and excavated but also wrote extensively on his interpretations of what Moche was. Larco conceived the Mochica as a centralized state, with a capital in the Moche Valley at the Huaca del Sol and the Huaca de la Luna (Larco Hoyle, 1938; 1939). He believed that the Moche populace was ruled by religious and military authorities, whose power derived 
from both ritual performance and physical coercion through military might and who spread their empire up and down the north coast. ${ }^{1}$

Larco's model was unquestioned by the members of the Viru Valley Project (Strong, 1947; Strong \& Evans, 1952; Willey, 1953), in the 1940s, and it was built upon by Harvard's Chan Chan-Moche Valley project in the 1970s. Specifically, Teresa Lange Topic (1982) interpreted the Huaca del Sol as the chief administrative center of the expansionist state and the Huaca de la Luna as the temple complex where, as Michael Moseley (1992) later phrased it, the "national pantheon was attended to". There were many other scholars working on Moche topics in the 1950s through the 1970s, of course (e.g. Benson, 1972; Donnan, 1973; 1975; Kutscher, 1950; 1967), but the issue of political organization usually was not of primary concern to them.

Moche studies dramatically changed in the last half of the 1980s, gaining momentum into the 1990s. The discovery of elite burials at Sipán (Alva, 1988; 1994; Alva \& Donnan, 1993) drew renewed interest in the Moche, in general, and underscored the wealth and power of a relatively small ceremonial center far from the Moche Valley. Equally or more importantly, a number of separate studies started to unravel the single ceramic sequence, developed by Larco, which had underpinned both the idea of a uniform Moche polity and of the spread of that polity from a single center in the Moche Valley. Such studies included work by Makowski (1994) in Vicús where Mochica-style metallurgy was associated with a ceramic style at variance with the Mochica ceramics from farther south.

Larco's five-phase sequence was done even more serious damage by the work of Castillo \& Donnan (1994) at San José de Moro, in the Jequetepeque Valley. In brief, they argued that the ceramic sequence of the northern North Coast (from the Jequetepeque Valley, northwards) was significantly different than that of the southern North Coast (from the Chicama Valley, southwards). This led to the proposition that political systems in each region differed as well and this perspective appears to have been generally accepted by most Moche scholars.

The view of a single Moche conquest state spreading from the Moche Valley underwent considerable modification. This work has mostly been carried out through the noting of different ceramic styles and is in evidence in two of the papers presented at the conference (Castillo Butters N.D.; Donnan, N.D.) and similarly is being pursued through an examination of variability in metal work (Fraresso, 2007). Since views of Moche rapidly outpace the publication of them, my view of current views of Moche variability is a sense I have gained from other colleagues rather than on specific publications. There are now, however, several different such views. They are 1.) A single, expansionist Moche state. 2.) A southern Moche state with valley-based polities in the north. And 3.) Valley-based or smaller polities throughout the north coast.

1 For a more extended discussion of the history of Moche studies, especially in relation to political organization, see Quilter \& Castillo, 2010. 
Few active Moche scholars seem to maintain the view of a single Moche state with an empire that spread from the Moche valley to the north and south, so it will not be discussed at length here. That view seems mostly to be held in the secondary literature. The idea of an expansive Moche in the south still is maintained by a number of scholars, however (Bourget, 2003; Chapdelaine, 2010; Millaire, 2010) although even they sometimes question the nature of Moche expansion, no longer necessarily assuming that it was a military enterprise. As for the north, increasingly, the region is being broken into smaller units from an original conception of a larger, "North Coast Moche" entity (Castillo \& Donnan, 1994). Finally, there are those who see Moche political organization as locally based, probably mostly focused on a single valley with the possibility of more than one polity within a valley. I have proposed this model (Quilter, 2002), with caveats, and the argument is implicit in Donnan's (2010) work.

It should be noted that there is a body of Moche literature in which political organization is not mentioned at all because authors' interests lie elsewhere. Commonly, this is found when Moche art and iconography are discussed (e.g. Pasztory, 1998) and implicit or explicit references to the concept of a Moche "corporate style", following Moseley (1992: 179) are often expressed within this perspective. Thus, while political issues are not addressed directly there is an assumption of relative uniformity in art and a concurrent uniformity in political organization, either as a wide spread state system or as a wide spread art and cultural system relatively independent of politics.

Recent research offers opportunities to evaluate these models of Moche political organization. Before doing so, however, I wish to consider the fundamentals of the materials by which we study Moche and then also examine so fundamental political concepts which may be in operation in considering the organization of Moche society.

\section{THE DATA BASE: MOCHE AS AN ARCHAEOLOGICAL CULTURE}

All prehistoric archaeology is faced with the task of interpreting past human behavior through material remains. Moche is, first and foremost, a concept and that concept is in the form of an "archaeological culture". The "archaeological culture" has been one of the most fundamental analytical tools of archaeology for many years. It perhaps was most clearly defined by V. Gordon Childe in the 1920s:

"We find certain types of remains - pots, implements, burial rites and house forms - constantly recurring together. Such a complex of associated traits we shall call a 'cultural group' or just a 'culture'. We assume that such a complex is the material expression of what today we would call 'a people' (Childe, 1925).

By the late 1960s and 1970s, the one-to-one correspondence of an archaeological assemblage with an ethnic or cultural group was already being undermined, most notably in the Binford-Bordes debate over the interpretation of Mousterian assemblages in southern France (e.g. Binford \& Binford, 1966; 1969; Bordes, 1969; 
Bordes \& de Sonneville-Bordes, 1970). Ironically, this trend, started by the New Archaeologists, accelerated to the point of undermining the Processualist project altogether. Anthropologists have increasingly rejected the concept of "culture" (see Nielsen, 2007) in favor of "society" and many Post-Processualist archaeologists, following suit, are more comfortable with considering how "identities" may shift and change through time rather than seeing static "archaeological cultures" closely linked to artifact assemblages.

I believe that many Moche scholars are still following programs of investigation in which we see "pots as people". Variability in ceramic styles is taken as representing different kinds of Moche. Both Donnan's and Castillo's reconsiderations of the northern Moche are based on ceramic studies. These studies as well as many others suggest that the distinctive and powerful iconography expressed on ceramics as well as aspects of their fabrics and forms are direct expressions of Moche social and political units. Although I will touch upon this question later in this chapter, the topic is too large to address here. It seems reasonable to propose, however, that the distinct sub-styles that have been and are being distinguished in both spatial and temporal dimensions on the North Coast reference some kind of socio-political behaviors and beliefs although what those are, exactly, may require careful considerations.

If we proceed with the assumption that changes in Moche ceramic (and other material) styles are proxies of varying of socio-political phenomenon then we may consider what current trends suggest. If the northern Moche realm is increasingly being balkanized into relatively independent, valley based political units, then we might propose that it is only a question of time before the same process will occur in the southern Moche realm as well.

The break-up of northern Moche is due to scholars identifying distinctions within what was previously viewed as a more general, uniform phenomenon. In large part, this is the result of an increasingly greater data set of archaeologically excavated materials with good chronological and temporal controls. Prior to the early 1990s, the century of study of Moche ceramics and other artifacts was mostly based on unprovenienced collections and so scholars were forced to talk in generalities, for the most part.

The deconstruction of a uniform Mochilandia appears to be already underway in the southern zone. In the Viru Valley, Steve Bourget's (2003) work at the ceremonial center of Huancaco revealed a "non-Moche" occupation in the "heartland" of Moche culture. The "non-Mocheness" of the site is seen primarily in ceramics which do not appear to follow the standards by with Moche is identified and by some variations in murals. Bourget (2003) maintains that the Huancaco phenomenon was ended by the sever El Niño events of A.D. 550-600 with a subsequent conquest by the Moche from the adjacent valley. Published radiocarbon dates leave this as one possible explanation among many.2

2 Bourget (2003: 266) presents three dates. Two are associated with the last occupation of a temple structure. Calibrated at the 2-sigma standard deviation they date to 635-865 and 530-680 A.D. The 
In a similar but slightly different set of data and interpretations, Jean-François Millaire (2010) sees Moche expansion as a relatively benign event in which another ceremonial center in Viru, the Huaca Santa Clara, was "allowed" to continue in operation under a Gallinazo regime while Moche elites established themselves in the small community of Huaca de la Cruz.

A third example is farther to the south, in the Santa Valley. There, Claude Chapdelaine (2010) identified two phases of Moche occupation in the lower valley. A relatively small huaca with Moche ceramics was constructed on a northern terrace of the site of El Castillo, dominated by a larger Gallinazo structure. After the collapse of El Castillo, a Moche occupation which included a large urban area was occupied at Guadalupito. Similar to Bourget, Chapdelaine sees both of these occupations as having occurred after the severe El Niños of the late 500s. 3

Whether or not Moche purported "expansions" into Viru, Santa, and other valleys to the south were due to warfare or stresses produced by El Niño events are topics which cannot be fully covered here in detail. Indeed, the entire issue of the appearance of Moche in the southern valleys cannot be adequately evaluated until detailed site reports are published of the research carried out at the sites in question. This is particularly so because the nature of the manifestation of the Moche style will be a critical factor in evaluating the nature of its adoption or implementation in the southern region. Depending on how Moche is defined will determine when it "appears" in the archaeological record.

Are the differences in ceramic styles and mural art in the southern valleys documented by the various researchers who have been working in them indicative of "non-Moche" occupations followed by "Moche" occupations? I would suggest that the Huancaco style, for example, would have simply been seen as a variant of Moche if the ceramics had been found in a museum with poor provenience records. In short, the same variability in Moche on a valley- by-valley basis as seen in the north may be true in the south.

If we are beginning to see not one Moche style but many Moche styles, then we must return to the question of how we interpret similarities and differences of such styles. Part of this issue has to do with the fact that the Moche ceramic style is representational and for many years we have identified gods, warriors, priests, and other individuals that seem to be repeated through time and space, with a few notable exceptions. The Moche religious system has been assumed to have been fairly constant over a long period of time and throughout a wide geographical area (Donnan, 2010) but I submit that this does not necessarily mean that political

third date, associated with a metal workshop, is interpreted as contemporary with the last period of use of the temple before abandonment and, at the calibrated, 2-sigma range, date to 370-640 A.D. The dates for the Moche Huacas (Chapdelaine, 2003: 280, Fig. 22.19) cover this range and go beyond it, to later dates but whether this can be used as a basis for the interpretation of a Moche conquest of Huancaco is a topic too long and involved to discuss here.

3 The dates (calibrated, 2-sigma) are as follows for El Castillo: 375-565, 525-655, and 540-685 A.D. For Guadalupito: 320-595, 425-660, 555-720, 595-775, 605-775, and 635-775 A.D. (Chapdelaine, 2010: Table 2). 
systems were equally widespread and stable. There are plenty of examples of relatively uniform religious systems that were shared by politically separate, often conflicting societies. Classical Greece with its shared Olympian pantheon and Medieval Western Europe with its common Christianity are two cases in point. We will return to the issues of the Moche religious system shortly. But let us first consider politics, in general.

\section{AGAINST THE STATE}

Nulle terre sans seigneur, Nul seigneur sans terre (No land without a lord, no lord without land) (Boissonnade, 1927: 120): this elegant, powerful phrase was a fundamental principle of feudal law in Medieval Europe. The aphorism simultaneously expresses two points: political office exists in relation to the ownership of land and land is to be incorporated within political boundaries.4 So too, today, we measure political power on the basis of the possession of land. It is no accident that in English the term "real estate" refers to properties for sale or purchase: land is real wealth. Whether interpreted through Marxist, capitalist, or other models, much of the politics of the modern world has involved disputing territories carried out within the context of state societies. Modern state societies define themselves externally by territorial boundaries and, internally, by defining the nature of property rights, particularly that of land.

Given these considerations it is no wonder that much of archaeology since the end of World War II has been focused on questions of the nature and origins of the earliest state societies. This intellectual project was carried out by historians, such as Toynbee (1934-1961) and certain sectors of practicing archaeologists, particularly those with evolutionary and neo-evolutionary theoretical agendas, in the 1960s and 1970s. Now, in our Post-Processualist age, many are calling into question the project they subscribed to in their youth, such as Norman Yoffee (2005) in his recent book, Myths of the Archaic State. Such efforts rarely call for the abandonment of the paradigm of the notion of the evolution of social complexity, however, and many reevaluations of the origins of the state result in modified interpretations, such as recent works by Bruce Trigger (2003) and Adam T. Smith (2003).

Almost all of the arguments about the nature of Moche politics include discussions about the nature of the territorial units in question. Bruce Trigger, for example, distinguishes between City-States and Territorial States and in each case, territory is a critical aspect of the definition:

"The distinction between these two types of states...rests not only on the size of territories but also on differences in the nature of their urban centres and in their economic and political organization" (Trigger, 2003: 92)

4 Even this feudal law ultimately is more about social relations that the primacy of property, per se because the saying was used to remind vassal and lord of their mutual obligations, based in the providing of lands and their maintenance — their buen gobierno-. 
The distinctions Trigger makes may be important but by insisting that territory is the crucial determinant of political formations - what they are "all about". But it may be worth stepping back from this perspective and question whether territory is at issue, at all, in the case of Moche. In several different works, the ethnohistorian Susan E. Ramírez (e.g. 1996; 2005) has challenged the notion of the Inca state as territorial. As the Inca are the best documented Andean political unit and therefore a potential model to compare and contrast with Moche, a brief review of Ramírez's argument is in order, here.

Ramírez (2005) argues that the Spanish interpreted the Inca Empire through European concepts which assumed that territorial boundaries were essential to the definition of the state. A salient example of this is the use of the term "Cuzco". Ramírez notes that in the earliest chronicles the reference to the urban center is to the "City of the Cuzco". The term "Cuzco" referred to the head of state, he who has come to be known to us as the Sapa Inca. Like many monarchs, the Inca leader had multiple titles of which Cuzco was one. Fairly quickly in the Colonial Period, there was a shift in which the Spanish first referred to "the City of the Cuzco" - the city of the ruler one of whose names was "the Cuzco". Later, according to Ramírez, the Spanish shifted usage, calling the city Cuzco as if the urban center had that name, like a European. But Ramírez's point is that Cuzco was first and foremost the title of a ruler.

Ramírez argues further that the political organization of the Inca Empire - the Tahuantansuyu or "Four Quarters" and the suyus, the divisions of them-, were not territorial or geographical terms but related to groups of people. Such groups did map onto terrain but the primary reference in the organization of the empire was human subjects, not territory. Ramírez makes the same argument for the organization of the Chicama Valley in the early Colonial Period (1996). Western concepts of "property" and land "ownership" did not exist. Usufruct rights adhered to those who worked the land so long as they kept it in production but no rights of property were attached to such claims. Curacas did not control or own land. In short, the Andean equivalent to European feudal law was: "No people without a lord, no lord without a people". But even this is not fully true, because political leadership was tenuous, at best.

Curacas only "ruled" by the consent of the governed. They were more like classical "big men" in the terms of evolutionary theorists. "Good government", the term used by Guaman Poma in his letter to the Spanish king, in Andean concepts consisted of curacas who put their people first by generously providing them with food and drink and other things and who took their well being into account in dealing with more powerful authorities. Leaders commonly were self-made by producing many children. The Sapa Inca's many wives and the practice of wife-giving by the Inca to loyal subjects were all part of this process: the more wives, the more children, and the more children the more the progenitor (father and successively, grandfather, great-grandfather, etc.) created his own "political" following.

Kin-based politics did not prevent groups (ayllu) of dissatisfied lineage sub-units from breaking away from a "natal" group to ally with another group since kinship ties 
likely could be found (or created) to link with many different relatively independent communities in any given area. Such fissioning and joining were common in the Colonial Period with the collapse of political units due to depopulation resulting from disease and general destabilization in the wake of war. There is every reason to assume that such processes occurred in prehistory as well. 5

Various critiques of Ramirez's proposal may be raised, and the Inca's interest in territory is in bountiful evidence in the form of ceques, cities shaped as pumas, and other marking of the sacred landscape. But her point that the primary references and concerns for ancient people were people, themselves, is worth considering.

\section{THE STATELESS MOCHE}

There is no evidence for a Moche state based on archaeology. All of our models of Moche political organization, as is true for most prehistoric cases, are inferences built upon archaeological data which may be interpreted in a number of ways. Ceramics portray gods and other mythological creatures, warriors in combat, scenes of sacrifice and ritual. No conclusive evidence of political systems is in evidence, in my opinion, although representations of various kinds of office holders (such as priests of different kinds and, possibly, various ranks of warriors), among others, are present.

Beyond ceramics and other portable objects, field archaeology does not sustain the theory of a Moche state, even by the standards of evolutionists. There is no clear evidence of a four-tier settlement hierarchy and there is no evidence that large huaca centers had extensive storage capacities for surpluses, among other lacking evidence.

For many years, the huge sizes of the huacas in the Moche Valley were the bases by which the idea of a Moche expansionist state was maintained. Also, Santiago Uceda suggests, in this present volume, that the Huaca del Sol was a late construction. Whatever the specifics of the growth of the Moche Valley huacas, the sizes of constructions there or anywhere else cannot necessarily be used to gauge relative political power. As but one example, Sparta was not impressive when it was at the height of its power and while its rival, Athens, did construct the acropolis, other Greek city states, such as Corinth or Thebes, built many large, beautiful buildings but were minor political powers. The same can be said for the Maya (A. Herring, personal communication) and many other ancient societies framed as "states."

A primary fallacy of the (neo-) evolutionary perspective is that it places agency in institutions or generalized concepts of ethnic entities in the past: "the state rose and fell", "the Moche expanded from one valley to the next". These are concepts: "chiefdoms", "states", and "ethnic" groups which may or may not have existed

5 The degree to which the Inca were successful in manipulating this system is a subject of much discussion and is not germane here. 
in the past and which are very hard to identify with confidence when studying archaeological data. Nevertheless, I think that there is considerable evidence for general long-term patterns in the Andes in which the most powerful social actors were not rulers but the majority of people who "voted with their feet" in where and to whom they allied themselves.

In their work at Initial Period sites in the Lurín Valley, Richard Burger and Lucy Salazar-Burger $(1990 ; 1991)$ have suggested that many ceremonial centers competed for followers there. Elaborate public rituals in spectacular architectural settings attempted to draw followers from the local region and from afar. In neoevolutionary terms we might say that these centers were competing to capture energy surpluses. The development of Chavín de Huantar continued this pattern with the highland center achieving a position as an inter-regional center which eventually collapsed. There is good evidence to indicate that the same pattern of pilgrimage centers existed in many areas of Peru in the Late Intermediate Period and that the Inca appropriated these centers, such as Pachacamac, to its own uses.

Given this long-term pattern in the Andes for the Initial Period, the Early Horizon, the Late Intermediate Period, and the Late Horizon, we might reasonably expect that something similar held true for the Early Intermediate Period and the Middle Horizon. In all cases, the agents of change were not the centers, themselves, but people who chose to develop various cults and even more people who chose to make pilgrimages to such centers or otherwise participate in activities in them - to "buy into the system", at least for the length of a ceremony, perhaps, and presumably, by identifying their interests with those of one ceremonial center as opposed to another. States were not opportunistic (c.f. Castillo, 2010), people were. "Tip" O'Neill, a former Massachusetts Congressman and Speaker of the House of Representatives of the United States, once said, "All politics is local". This applies to the Ancient Andes as much as it does anywhere else. Of course, there are examples of attempts of the expansion of groups organized as polities from one region to the other but, ultimately, polities were operating at the local level first and then, secondarily interacting with larger scale phenomena. The people who used Moche ceramics and visited Moche temple complexes were enmeshed in such local politics and it seems reasonable to interpret that the nature of the local-level system was something like the general system of kin-based organization described by Ramírez. In its time, Moche was one of those pan-regional systems participated in by people whose livelihoods and identities were founded on a local basis.

\section{WHAT MOCHE WAS}

So, what was Moche? It mostly was a religion. It was not an ethnic group nor the organ of a state (c.f. Donnan, 2010) but a religion unto itself. 6 It was a religion-asa-cultural-system, in the sense of Clifford Geertz (1965):

6 Donnan uses the term "state religion", in the title of his chapter in New Perspectives on Moche Political Organization (Quilter \& Castillo, 2010). In the chapter, itself, however, he makes clear that 
"Religion is... a system of symbols which acts to... establish powerful, pervasive and long-lasting moods and motivations in men (sic.)... by formulating conceptions of a general order of existence and... clothing these conceptions with such an aura of factuality that... the moods and motivations seem uniquely realistic".

Moche was a religious-cultural system which attempted to convince people that its leaders correctly understood the "general order of existence" and had some control or influence over that order which could be of benefit to those people who came to the temple complexes and claimed to subscribe to the system being practiced there. Mochica art which draws so much attention from modern scholars and the public was part of that system.

In other words, I suggest that the kind of people-based system Ramírez describes was the basic political architecture by which individuals and their affiliated groups organized themselves. Moche was a phenomenon that successfully co-opted that system, drawing some leaders (curacas) and their followers into it. Like the Inca Empire of later times, the Moche system likely claimed to offer something new while claiming to restore or reaffirm "traditional" or "universal" practices, values, and beliefs.

Moche clearly was successful, as in evidence by its strong signature in the archaeological record. Moche at its peak also may have been an identity which was assumed by some people, some times. It served to create social bonds and links between different units, probably cross-cutting the traditional "vertical" ties of kinship and likely serving as a means of pan-regional elite interactions.

Many of the larger Moche centers are located in less-than-ideal places in the landscape. The El Brujo complex is on an alternately windy and cold or boiling hot, dusty terrace at the edge of the ocean and at the end of the irrigation system. The Moche Huacas are also low in the valley. What does this tell us about how power was constituted? If water was the most important resource, then control of the upper-middle valley, at the irrigation intakes, would have been the most powerful locale, as it was on the Central Coast in the Initial Period. The fact that the large Moche huacas were in lower valley locations means that, for a while, their religious cults were able to control resources from afar or that they did not have direct control in the first place. More likely, perhaps, the centers were established in marginal locales but, through time, the cult priests used religious authority to achieve control.

In other words, Moche may have been a system which was developed (consciously or unconsciously is hard to say) by people in marginal or peripheral geographical and, more important, social locales as a means by which to achieve success in a

he sees independent polities united by an "overall sense of unity within the Moche world" through a common religion. In a general sense, we are in agreement. I am uncertain to what degree various communities on the North Coast were practicing religious systems deriving from shared traditions versus the adoption of specific cult practices which may have originated from a specific source, most likely the Moche Huacas, as I discuss later in this chapter. Indeed, I think that it is this issue which will be worth pursuing in future research. 
highly competitive natural and social landscape. These centers, such as well as San José de Moro - located at a central node in contested agricultural lands (Castillo, 2010) - were not simply in the landscape but created new cultural landscapes, re-orienting the geo-politics of their valleys towards themselves and away from the traditional (and "real") centers of power. It has been noted by many scholars, for example, that the Moche Valley is one of the smallest on the North Coast. This opens the door to explain the expansion of Moche in the mode of circumscription theory (Carneiro, 1970). The same conditions serve to propose that it was not military might but a religious cult that was generated, however (e.g. Rathje, 1972).

As I have said elsewhere (Quilter, 2002), any interpretation of what Moche was must confront the fact that the archaeological record appears to indicate duration of the art style for over seven centuries.7 But while a general suite of gods, myths, and rites appears to have had longevity on the North Coast of Peru, further study, with more and better controlled data sets and less reliance on looted collections, may identify temporal and regional variability. ${ }^{2}$ And if we start to be able to document that variability when will we say Mochica started?

At the Huaca Cao Viejo, at the El Brujo Complex in the Chicama Valley, archaeologists recently discovered the Señora de Cao. This was a high-status Mochica woman who was buried in the huaca with a sacrificial victim and much wealth. The wealth included many items of jewelry and 20 spear-throwers, possibly offerings from regional leaders. The dates for the burial are in the later 400s A.D. The decorations of the chamber in which the Señora were buried could be called Mochica but could also be called "generalized North Coast" styles. The same is true for the pottery buried with her. They are "Mochica" so long as the term is a loosely applied, broad ranging one.

The terraces of Huaca Cao Viejo at the time the Señora was interred were painted in solid colors with no distinctly "Moche" designs (again, unless one wants to call everything on the North Coast at this time as "Moche") and the same is true for the decorations of interior courtyards (recintos).

We might attempt to find correlations between the costume of the Señora and the Presentation Theme/Sacrifice Ceremony and therefore say that this is a Moche señora but I think we could equally argue that she and her temple were not part of the Moche religious complex. This depends on how we define Moche and as we refine our view of the Early Intermediate Period and the early Middle Horizon on the North Coast this problem is going to become increasingly complex until we confront and perhaps revise our definitions. These problems have already arisen in attempting to fit the information Steve Bourget has uncovered at Huancaco, in the Viru Valley -one of the "heartland" areas of Moche culture- as well as our grappling with how the Castillo ceramic series, formerly thought to be emblematic of the "Gallinazo" archaeological culture, do or do not fit into our definition of "Moche".

7 Future research may indicate that the "fully developed" Moche system was of relatively short duration.

8 I believe the variability is already in evidence but needs to be more fully explicated than at present. 
In the last major building phase at Huaca Cao Viejo, the front terraces of the huaca were decorated with motifs (nearly) identical with those at the Huaca de La Luna where the artistic program had been carried out through many construction phases, presumably for centuries. There also is evidence that recintos on the summit of Huaca Cao were built which followed Huaca de la Luna canons. This seems to me to be the only clear case we have of the direct intervention of the Moche Valley system beyond its borders. Apparently, whatever the nature of that extension and its causes were, the two valley unity in art and ritual and, presumably, of political alliance or dominance, did not last very long because no major building phase follows at Huaca Cao after the implementation of the Huaca de la Luna program. As a caveat to all I have said, above, I think that it is important to remember the importance of water, irrigation systems, and land in the Moche valley systems. Access to or control over these resources would have been vital to people, especially if under demographic and other pressures. We might therefore consider that at some point during the Early Intermediate Period and early Middle Horizon when the Moche style was common on the North Coast, that such issues played into how that style was linked to political dynamics. In other words, we should not discount that Moche identity, politics, and warfare became more tightly intertwined at some time periods than at others. The system that Ramírez describes may have been a basal way in which people organized themselves for long periods of time but it came into being at a particular time and place. Or, alternatively, that kinbased system may have been over-ridden by attempts, some successful others not, perhaps, of more institutionalized political systems. Moche may have been one such system that was co-opted into being a more engaged political entity at some times and places. The Moche-Chicama connection may have been such a case, late in the day of the Moche phenomenon and apparently only successful for a short period of time.

\section{CONCLUDING THOUGHTS}

In concluding, I want to re-emphasize that I believe that Moche dynamics were complex just like any cultural phenomenon that was strong enough to leave its imprint on the landscape must have been. It is likely that political alliances that may have included attempts at military expansion did occur in the several centuries during which the Moche phenomenon occurred. The example of the late period relations between the Moche and Chicama Valleys currently is the clearest example we have of some kind of political interactions but there will likely be more in the future. My main point, however, is that what we see as Moche is primarily a religious cult and moving beyond this to interpreting social political phenomena moves us a step away from our data and therefore requires that we be cautious.

In discussion during the conference that resulted in this chapter, Luis Jaime Castillo noted that the overwhelming majority of ceramics that have been the basis of 
most interpretations of Moche iconography, politics, and other matters, come from the Chicama Valley, especially in the collections of Rafael Larco Hoyle and, now, the Larco Museum. This is a very important point with its suggestion that our conception of the Moche style has been anchored to a particular time and region. The Chicama styles have served as the baseline, the starting point, the prototypes, from which we have judged whether or not other styles are or are not "Moche". But the Moche-Chicama style is apparently only one variant of a much more polymorphous Moche style, if one exists at all. The question of how ceramic styles express political or social groups is one topic I have raised here and, clearly, much more work needs to be done on this matter.

So too, I believe that we should avoid discussing whether or not the Moche were a "state" and concentrate on how Moche religion and politics are in evidence from as close a reading of the archaeological data as possible. Rather than attempt to determine whether or not Moche archaeology expresses the material culture that may be marked off a check-list as necessary to identify a state or complex chiefdom we should investigate how Moche society and politics were constructed, by the Moche themselves, on the ground.

This is not to demote the Moche from the ranks of "complex societies". Moche, whatever it was, was the product of historically contingent forces played against long-term patterns of behavior in which common people were the primary agents. They may have "bought in" to ideologies and been drafted into the ranks of armies to fight for abstract causes, but they also were the agents of resistance to such forces. This has been true everywhere, at all times, and offers us hope for our present situation, as well.

\section{Acknowledgments}

Thanks to Richard L. Burger and Adam Herring for constructive criticisms of an earlier draft of this article. I am especially grateful for the opportunity to visit the Institut de Recherche sur les ArchéoMATériaux, Université Michel de Montaigne, Bordeaux and to participate in the Round Table there, October $23^{\text {rd }}-25^{\text {th }}, 2007$. Many people made that visit pleasant and productive particularly Michel Pernot, Director of Research and Carole Fraresso. Luis Jaime Castillo B., Santiago Uceda C., and Christopher Donnan were very helpful there and in Peru. I appreciate such fine colleagues.

\section{References Cited}

ALVA, W., 1988 - Discovering the New World's richest unlooted tomb. National Geographic, 147 (4): 510-548; Washington D.C.

ALVA, W., 1994 - Sipán, 331 pp.; Lima: Cervecería Bacus y Johnston, S.A..

ALVA, W. \& DONNAN, C. B., 1993 - The Royal Tombs of Sipán, 299 pp.; Los Angeles: Fowler Museum of Cultural History, University of California.

BENSON, E. P., 1972 - The Mochica: A Culture of Peru, 164 pp.; New York and Washington: Praeger Publishers. 
BINFORD, L. R. \& BINFORD, S. R., 1966 - A preliminary analysis of functional variability in the Mousterian of Levallois facies. American Anthropologist, 68 (2).

BINFORD, L. R. \& BINFORD, S. R., 1969 - Stone tools and human behavior. Scientific American, 220: 70-84.

BOISSONNADE, P., 1927 - Life and Work in Medieval Europe; New York: A.A. Knopf.

BORDES, F. H., 1969 - Reflections on typology and techniques in the Paleolithic. Arctic Anthropology, 6: 1-29.

BORDES, F. H. \& SONNEVILLE-BORDES de, D., 1970 - Signficance of variability in Paleolithic assemblages. World Archaeology, 2 (1): 61-73.

BOURGET, S., 2003 - Somos diferentes: dinámica ocupacional del Sitio Castillo de Huancaco, Valle de Virú. In: Moche: Hacia el Final del Milenio (S. Uceda \& E. Mujica, eds.): Volume II: 245-267; Trujillo: Universidad Nacional de Trujillo, Pontificia Universidad Católica del Perú. Actas del Segundo Coloquio sobre la cultura Moche (Trujillo, 1 al 7 de agosto de 1999).

BURGER, R. L. \& SALAZAR-BURGER, L., 1990 - The chronology and function of Cardal's public architecture. Paper presented at the 18th Annual Midwest Conference on Andean and Amazonian Archaeology and Ethnohistory; Chicago: University of Chicago, February 24.

BURGER, R. L. \& SALAZAR-BURGER, L., 1991 - The second season of investigations at the Initial Period center of Cardal, Peru. Journal of Field Archaeology, 18 (3): 275-296.

CARNEIRO, R., 1970 - A theory of the origin of the state. Science, 169: 733-738.

CASTILLO, L. J., 2010 - Moche politics in the Jequetepeque valley: A case for political opportunism. In: New Perspectives on Moche Political Organization (J. Quilter \& L. J. Castillo B., eds.); Washington: Dumbarton Oaks Research Library and Collection.

CASTILLO B., L. J. \& DONNAN, C., 1994 - Los mochicas del norte y los mochicas del sur, una perspectiva desde el valle de Jequetepeque. In: Vicús (K. Makowski ed.): 143181; Lima: Banco de Crédito del Perú.

CHAPDELAINE, C., 2003 - La ciudad de Moche: urbanismo y estado. In: Moche: Hacia el Final del Milenio (S. Uceda \& E. Mujica, eds.): Volume II: 247-285; Trujillo: Universidad Nacional de Trujillo, Pontificia Universidad Católica del Perú. Actas del Segundo Coloquio sobre la cultura Moche (Trujillo, 1 al 7 de agosto de 1999).

CHAPDELAINE, C., 2010 - Moche political organization in the Santa Valley: a case of direct Rule through gradual control of the local population. In: New Perspectives on Moche Political Organization (J. Quilter \& L. J. Castillo B., eds.); Washington: Dumbarton Oaks Research Library and Collection.

CHILDE, V. G., 1925 - The Dawn of European Civilization; New York: Knopf.

DONNAN, C. B., 1973 - Moche occupation of the Santa Valley, Peru, 240 pp.; Berkeley: University of California Press. University of California Publications in Anthropology, Vol. 8.

DONNAN, C. B., 1975 - The thematic approach to Moche iconography. Journal of Latin American Lore, Vol. 1, n. ${ }^{\circ}$ 2: 147-162; Los Angeles: Latin American Center, University of California.

DONNAN, C. B., 2010 - Moche state religion: a unifying force in Moche political organization. In: New Perspectives on Moche Political Organization (J. Quilter \& L. J. Castillo B., eds.); Washington: Dumbarton Oaks Research Library and Collection.

FRARESSO, C., 2007 - L'usage du métal dans la parure et les rites de la culture Mochica (150-850 ap. J.-C.), Pérou; Bordeaux: Université Michel de Montaigne, Bordeaux 3, France. Doctoral dissertation. October $22^{\text {nd }}$. 
KUTSCHER, G., 1950 - Chimu, eine altindianische Hochkultur; Berlin: Verlag Gebr. Mann. KUTSCHER, G., 1967 - Iconographic studies as an aid in the reconstruction of early Chimu civilization. In: Peruvian Archaeology, Selected Readings (J. H. Rowe \& D. Menzel, eds.): 115-122; Palo Alto, CA: Peek Publications.

LARCO HOYLE, R., 1938 - Los Mochicas, Tomo I; Lima: Casa Editora La Crónica y Variedades.

LARCO HOYLE, R., 1939 - Los Mochicas, Tomo II; Lima: Empresa Editorial Rimac S.A.

MAKOWSKI HANULA, K., 1994 - Los señores de Loma Negra. In: Vicús (K. Makowski et al., eds.): 83-141; Lima: Banco de Crédito del Perú. Colección Arte y Tesoros del Perú.

MILLAIRE, J.-F., 2010 - Moche political expansionism as viewed from Virú: recent archaeological work in the close periphery of a hegemonic city state System. In: New Perspectives on Moche Political Organization (J. Quilter \& L. J. Castillo B., eds.); Washington: Dumbarton Oaks Research Library and Collection.

MOSELEY, M. E., 1992 - The Incas and Their Ancestors, 272 pp.; London \& New York: Thames and Hudson.

NIELSEN, F. S., 2007 - Culture. Entry in the Online Dictonary of Anthropology, http://www. anthrobase.com/Dic/eng/index.html

PASZTORY, E., 1998 - Pre-Columbian Art, 176 pp.; Cambridge \& New York: Cambridge University Press.

QUILTER, J., 2002 - Moche politics, religion, and warfare. Journal of World Prehistory, 16 (2): 145-195.

QUILTER, J. \& CASTILLO B., L. J., 2010 - Many Moche models: an overview of past and current theories and research on Moche political organization. In: New Perspectives on Moche Political Organization (J. Quilter \& L. J. Castillo B., eds.); Washington: Dumbarton Oaks Research Library and Collection.

RAMÍREZ, S. E., 1996 - The World Upside Down: Cross-Cultural Contact and Conflict in Sixteenth-Century Peru, 240 pp.; Stanford: Stanford University Press, CA.

RAMÍREZ, S. E., 2005 - To Feed and Be Fed: The Cosmological Basis of Authority and Identity in the Andes, 376 pp.; Stanford: Stanford University Press, CA.

RATHJE, W. L. 1972 - Praise the gods and pass the metates: a hypothesis of the development of lowland rainforest civilization in Middle America. In: Contemporary Archeology (M. P. Leone, ed.): 365-392; Carbondale: Southern Illinois Press.

SMITH, A. T., 2003 - The political landscape: constellations of authority in early complex polities; 346 pp.; Berkeley: University of California Press.

TRIGGER, B., 2003 - Understanding Early Civilizations, xiii + 757 pp.; Cambridge University Press, Cambridge and New York.

STRONG, W. D., 1947 - Finding the tomb of a warrior-god. National Geographic Magazine, 91 (4): 453-482.

STRONG, W. D. \& EVANS, C. Jr., 1952 - Cultural Stratigraphy in the Viru Valley, Northern Peru: The Formative and Florescent Epochs; New York: Columbia Studies in Archaeology and Anthropology 4.

TOPIC, T. L., 1982 - The Early Intermediate Period and its legacy. In: Chan Chan: Andean Dessert City (M. E. Moseley \& K. Day, eds.): 255-284; Albuquerque: University of New Mexico Press.

TOYNBEE, A. J. 1934-1961 - A Study of History. 12 volumes published between 1934 and1961; Oxford: Oxford University Press. 
Moche: Archaeology, Ethnicity, Identity

WILLEY, G. R., 1953 - Prehistoric Settlement Patterns in the Viru valley, Peru; Washington: Smithsonian Institution, Bureau of American Ethnology, Bulletin 155.

YOFFEE, N., 2005 - Myths of the Archaic State: Evolution of the Earliest Cities, States, and Civilizations, xiii + 227 pp.; Cambridge: Cambridge University Press, Cambridge and New York. 